\title{
Application of African Customary Law: Tracing its Degradation and Analysing the Challenges it Confronts
}

\author{
Lisa Owino*
}

\begin{abstract}
Historically, African customary law has occupied the lower rungs of the legal ladder, often being set aside for more formal laws. This is primarily due to the introduction of western and religious legal systems through the exploration of western nations into Africa, missionary activity and, subsequently, colonisation. However, African countries - including Kenya - are making an effort to give due recognition to customary law. This paper discusses the steady degradation of customary law from the colonial period to the promulgation of the Constitution of Kenya 2010 where there are attempts to resuscitate its application, it also discusses the challenges that the courts may face in this application of customary law today and possible solutions to these challenges.
\end{abstract}

\section{Introduction}

In traditional African society, men from the same geographical area came together and formed tribes. These tribes formulated laws based on customs and beliefs for the common good. These customs applied exclusively to members of a specific community equivalent to the jurisdiction of the law in modern day. These laws and customs are now referred to as African customary law. ${ }^{1}$

During the pre-colonial period, traditional African communities adjudicated over any disputes in the community using their own customary law derived from the customs and societal norms of the time. These communities embraced

\footnotetext{
* The author is a student at the Strathmore University Law School in Nairobi, Kenya.

1 http://www.kenyalawresourcecenter.org/2011/07/genesis-of-african-customary-law.html\#sthash. ZfUkWDHe.dpuf on 11 September 2015.
} 
restorative values in resolving conflicts and in responding to wrongdoing. Civil and penal practices in these communities embraced restorative justice as understood today. Restorative justice can be defined as 'processes whereby parties with a stake in a specific offence collectively resolve how to deal with the aftermath of the offence and its implications in the future. ${ }^{2}$ It was fundamental as people did not exist as individuals but more as part of a community. Their entire lives were built on a web of societal relationships which had to be maintained as they formed part of that community. ${ }^{3}$ African customary law always emphasised the welfare of the community over the individual and thus the individual was forced to make decisions for the betterment of the community. The Xhosa community of South Africa believed in ubuntu which translates to 'I am because we are."4 Another interpretation is 'I am human because I belong to the human community and I view and treat others accordingly. ${ }^{5}$ In Kenya, the Kikuyu community granted rights of use of land to individuals according to their need whether the grantee had a right to control that land or not. ${ }^{6}$

Basically, traditional African communities used a justice system that was akin to the one used today. Parties were allowed to argue their case and present evidence before a number of adjudicators. Punishment or justice was meted out to the wrongdoer once guilt was ascertained. The only differences perhaps are that punishment was restorative as opposed to retributive and the verdicts did not hinge on argument but truth. Customary law and social norms were applied in adjudication with different communities applying their own specific laws and norms much like the jurisdictional use of law today. ${ }^{7}$

While Kenyan law does not formally define customary law, it is implicitly recognised in the constitution under Article 159(3). ${ }^{8}$ The Interpretation and General Clauses Ordinance of Tanzania gives the following definition: 'Any rule or body of rules whereby rights and duties are acquired or imposed established

2 Marshall T, Restorative justice: an overview (1999), <http://www.homeoffice.gov.uk/rds/pdfs/ occ-resjus.pdf $>$ on 29 August 2015. See also Braithwaite J, 'Survey Article: Repentance Rituals and Restorative Justice', The Journal of Political Philosophy (2000), 115.

3 Kinyanjui S, 'Restorative justice in traditional pre-colonial 'criminal justice systems' in Kenya' Tribal Law Journal (2009), 4.

4 https://2012spiritinaction.wordpress.com/2013/04/18/ubuntu-in-the-xhosa-culture-means-i-ambecause-we-are/> on 23 November 2015.

5 http://www.coe.int/t/dg4/cultureheritage/culture/Cities/Publication/BookCoE20-Chaplin.pdf on 24 November 2015.

6 http://www.fao.org/docrep/u8995e/u8995e06.htm on 23 November 2015.

7 The Akamba community of Eastern Kenya was used as a case study for this assertion in Kinyanjui S, 'Restorative Justice in Traditional Pre-colonial 'Criminal Justice Systems' in Kenya', 6.

8 Constitution of Kenya (2010). 
by usage in any Tanganyika African community and accepted by such community in general as having the force of law." Part I of this paper discusses the degradation of customary law from the time Kenya was declared a protectorate in 1895 to the promulgation of the 2010 Constitution. Part II discusses the challenges that the courts and the legal system have faced in the application of customary law and finally, Part III will provide possible solutions to these problems.

\section{The Degradation of African Customary Law in Kenya}

From the age of discovery in the 15th century to the colonisation of African states in the 20th, African customary law was degraded to pave way for modern models of law. This can be attributed to the introduction of westernised legal systems by the European settlers and of religious systems such as Christianity and Islam that had their own specific sets of laws. The introduction of canon law by the missionaries led to conversion of tribesmen from their indigenous law. ${ }^{10}$ Throughout the time of missionary activity from 1844 , when Kenya became a protectorate in 1895 and was finally declared a colony in 1920, customary law was used but not recognised as part of the country's legal system. Finally, with the imposition of the British judicial system during the colonial period and its subsequent continuation under the Kenya national government, authority for handling the more serious crimes was given to the police and courts. ${ }^{11}$

\section{The Colonial Era (1895-1963) ${ }^{12}$}

When Kenya was declared a protectorate in 1895, the British settlers were few in number and lacked sufficient resources to impose direct rule. Instead,

9 http://www.kenyalawresourcecenter.org/2011/07/genesis-of-african-customary-law.html\#sthash. ZfUkWDHe.dpuf on 11 September 2015.

10 The first missionary in Africa is claimed to be George Schmidt who arrived in Table Bay, South Africa in 1737. He established a mission station for the KhoiKhoi. In 1742, he baptised five Khoikhoi. They were the first indigenous African people to be converted to Christianity, South African history online <http://www.sahistory.org.za/dated-event/first-missionary-arrives-cape> on 5 September 2015.

11 Harkness S, Edwards C, Super C, 'Social roles and moral reasoning: a case study in a rural African community' Developmental Psychology (1981), 596.

12 This section discusses law from 1895 which was the year that Kenya became a protectorate, as opposed to 1920 when she became a colony; even in 1895, laws other than customary law were being applied by the settlers. 
they sought to exercise authority over the already established traditional dispute resolution mechanisms. ${ }^{13}$ As early as 1897 , the British administration formally recognised certain indigenous agents of dispute settlement by granting jurisdiction to existing 'courts' of local chiefs and councils of elders. Although avowedly based on traditional institutions, these systems were an integral part of the unitary judicial system of the Colony. ${ }^{14}$ Formal dispute resolution systems such as courts and tribunals were also introduced. These formal systems, however, only applied to Europeans and Indians ${ }^{15}$ while Muslims were subject to Islamic law. ${ }^{16}$ African customary law applied to all Africans ${ }^{17}$ irrespective of conversion to another religion. In Benjawa Jembe v Priscilla Nyondo, ${ }^{18} \mathrm{~J}$ Barth held that African customary law was applicable to the estate of an African who had abandoned the customs and become a Christian. This universal African application did little for the status of customary law. In $\mathrm{R} v \mathrm{Amkey}^{19}$ the question that arose during trial was whether a woman married under African customary law could testify against her husband. The common law deemed a husband and wife as one person and neither could be compelled to give evidence against the other. According to CJ Hamilton, a wife married under African customary law was not a legal wife or spouse under the formal law. Consequently, the court compelled her to give evidence against her husband. This case is indicative of how African customary law was degraded to the bottom of the legal food chain and made way for judicial precedence, ordinances and statutes.

In an ordinance to amend the Court's Ordinance ${ }^{20}$ these disparate bodies were reorganised into several hundred native tribunals, each consisting of as many as fifty or more elders. These, like their predecessors and successors, were instructed to apply 'the native law and custom prevailing in the area of the jurisdiction of the tribunal. ${ }^{21}$ The elders were presumed to know this customary law as an integral part of their inherited tradition, a reasonable presumption since

\footnotetext{
Article 2(b), Native Courts Regulations Ordinance, (1897).

14 Section 2(b), Native Courts Regulations. (No. 52 of 1897). See Phillips, 'Report on Native Tribunals (1945) 7-10.

15 Article 57, Native Courts Regulation Ordinance (this law was applied by the Mudirs and from 1907, the Liwali Courts).

16 Article 52, Order-In-Council (1897).

17 Ndulo M, 'African customary law, customs and women's rights' Cornell Law Faculty Publications (2011), 22.

[1912] 4 EALR 160.

[1917] 7 EALR 14.

Ordinance No.2 of 1930.

21 Abel R, 'Customary law of wrongs in Kenya: an essay in research method' Faculty Scholarship Series (1969), 587.
} 
they were men of little formal education, had few European contacts, and served exclusively within their own tribe. ${ }^{22}$ These native tribunals dealt with personal matters, customary crimes specific to a certain ethnic group and crimes under statute. ${ }^{23}$ However, these tribunals were not considered proper courts and thus were not part of the nation's legal system. In Lolkilite ole Ndinoni v Netwala ole $N_{e b e l e^{24}}$ the East African Court of Appeal dealt with two matters relating to the Maasai customary practice of blood money and the ability of Native Tribunals to apply the Limitation Ordinance of 1934. The appellant's father, who was deceased at the time of the case, had allegedly committed homicide and the matter was taken to the Native Tribunal. However, the claim for blood money was made at the native tribunal thirty-five years after the alleged homicide. The Tribunal dismissed the suit but the Supreme Court awarded the claim. The Appellant appealed to the East African Court of Appeal (EACA). The EACA dismissed the claim on the ground that it was repugnant to justice and morality to bring a matter for hearing after 35 years. It is clear that the EACA considered claims for blood money valid but rejected bringing the matter after a long period. Despite the ruling that indirectly supported the claim for blood money, Sir Edward CJ (Uganda) held that the Native Tribunals were not courts in the proper sense and therefore the Limitation Ordinance of 1934 was not applicable to them. The finding that the Native Tribunals were not proper courts, illustrates that Europeans attitude towards customary dispute resolution methods inferior to formal courts. ${ }^{25}$

The native tribunals were replaced in 1951 by the African Court in the African Courts Ordinance. ${ }^{26}$

\section{From independence (1963) to the New Constitution (2010)}

Before the enactment of the Magistrates Courts Act in 1967, the African courts applied customary law when dealing with personal or civil matters. These

22 Abel R, 'Customary law of wrongs in Kenya: an essay in research method', 613.

23 Kosele African Court Criminal Case no 33 of 1966 (the accused was charged with indecent assault contrary to Section 144 of the Penal Code and convicted for breaking the virginity of his victim and he was ordered by the court to compensate the victim with a heifer as per customary laws).

24 [1952] 19 EACA.

25 Kariuki F, Customary law jurisprudence from Kenyan courts: implications for traditional justice systems' (2015) http://www.strathmore.edu/sdrc/uploads/documents/books andArticles/ TDRM $\% 20$ and $\% 20 J u r i s p r u d e n c e . p d f$. on 8 October 2015.

26 No. 65 of 1951. 
courts fused principles of a fair hearing as known today, including the right to a public hearing, the right to an impartial tribunal, and the right to present evidence, the right to an effective remed ${ }^{27}$ among others while also respecting the customary law of the area that the court was situated in a tribunal, the right to present evidence, among others while also respecting the customary law of the area that the court was situated in.

In African courts, every man was his own advocate. ${ }^{28} \mathrm{~A}$ party could bring a claim for tortious actions like defamation and assault. Accusing someone of witchcraft with the intention to lead others to believe so was classified as defamation. ${ }^{29}$ Defamation had to be a statement made with the intention to defame and not just vulgar abuse uttered during a quarrel. ${ }^{30}$

Compensation ranged from livestock and money, ${ }^{31}$ following a schedule of compensation. For example, among the Kikuyu bodily injuries like the loss of an eye solicited amounts ranging from ten to sixty goats; for loss of a tooth, from one sheep to ten goats and a ram. ${ }^{32}$ In the Kisii community, a woman could file for divorce if she had been assaulted by her husband or he had practised or forced her to practice witchcraft. ${ }^{33}$ After filing for divorce, she could ask the court to order her husband to return any of her property that he retained. In Ukambani, if a man struck a corpse, he was liable for full blood money. This method of remedy satisfied the right to an effective remedy as victims were compensated for their losses.

27 http://www.achpr.org/instruments/principles-guidelines-right-fair-trial/ on 6 December 2015.

28 Thiong'o, N, The River Between' African Writer's Series, Nairobi, 1965 (The main character, Waiyaki, has to defend himself on the charge of betraying the tribe before the council of elders and the members of the tribe, signifying that trials were open to the public much like court proceedings today).

29 Kisumu DAC CC 299/66 (1966). (In this case, a wife -when confronted with rumours of the death of her son- accused her neighbour of witchcraft and alleged that his witchcraft was the cause, but the boy turned out to be alive and the court stated that the woman defamed her neighbour with her unfounded claims).

30 Kisii DAC CC 47/66 (1966) (plaintiff alleged that defendant had called her an adulteress, and claimed 200/- compensation; the court dismissed her claim as based on mere vulgar abuse uttered during a quarrel). See also the above case, Kisumu DAC CC 299/66 (where the plaintiff also alleged that the woman also called him a tenant of the land of others and demanded compensation for this statement. The court held that the statement was merely an insult and could not be classified as defamatory).

31 Kisii DAC CC 64/66 (1966) (100/- compensation awarded against defendant on his admission that he had called plaintiff a witch who had killed his child).

32 DAC CC 342/66 as cited by Abel, $R$, in 'Customary law of wrongs in Kenya: an essay in research method', 612 .

33 Kisii DAC CC 342/66 (1966) (a woman claimed for divorce after her husband shaved her hair and took her underwear to perform a "spell" on her). 
A number of evidentiary rules were applied: e.g., taking of testimony, examination, cross-examination, admittance of exhibits and corroboration. In Kisii, on October $5^{\text {th }} 1966$, for instance, a woman filed for divorce on the grounds that her husband and her mother-in-law practised and tried to compel her to practise witchcraft. She gave testimony and the judges examined her, asking her questions about the types of practices her husband engaged in. She was also required to produce evidence of the same. She showed the court her shaved head (the Kisii believed that hair could be used to cast a 'spell' on its owner) and her underwear that was taken from her mother's homestead. ${ }^{34}$

In 1967, the Magistrates Courts $A c t^{35}$ gave District Magistrates power to hear claims under African customary law. District Magistrates had jurisdiction all over Kenya and they effectively eliminated all African Courts in an attempt to unify the different laws governing the country. Section 2 of the Act limited the customary claims under the law to matters of land, intestacy, family, seduction of unmarried women and girls, enticement of married women to adultery and status of women and children. In Virginia Edith Wambui v Joash Ochieng Ougo and Omolo Siranga $a^{36}$ a dispute arose over the place of burial of S.M Otieno who died intestate. His widow wanted to bury him in Ngong while his clan wished to have him buried in his ancestral home. Both the High Court and the Court of Appeal held that an African man could only be buried according to the customs of the community since he could not completely disassociate himself from the customs and practices of his tribe. In Re Ogola Estates ${ }^{37}$ the testator drew a will that did not cater for his customary wife and the court held that this wife was not a wife for purposes of succession. These are a few examples where the court used customary law before 2010. Most of these cases fall within the scope of section 2 of the Magistrates Courts Act.

Effectively, courts only applied customary law as a guide in cases where written laws expressly provided for its usage. In Kamanza s/o Chiwaya v Manza $w / o$ Tsuma ${ }^{38}$ the High Court held that the list of claims under section 2 of the Magistrate Court Act was exhaustive and therefore barred customary law claims based on tort or contract. Claims based on tort and contracts were not included in section 2 of the Magistrates Courts Act.

\footnotetext{
Abel R, 'Customary law of wrongs in Kenya: an essay in research method', 612.

Cap 10, Laws of Kenya.

[1982-88]1 KAR.

[1978]KLR.

38 Unreported High Court Civil Appeal No. 6 of 1970.
} 
The above cases are a reflection of how the elimination of the African courts eroded the already slippery standing of customary law in Kenya's legal system.

\section{The Deliberate Resuscitation of African Customary Law in Kenya}

Article 159 (2) (c) of the Constitution of Kenya provides that courts are to be guided by the principles of traditional dispute resolution mechanisms. Article 159 (3) limits the application of traditional dispute resolution mechanisms by stating that they should not be used in a manner that contravenes the Bill of Rights, is inconsistent with the Constitution or other written laws or is repugnant to justice and morality or results in outcomes that are repugnant to justice and morality. Section 3 of the Judicature Act states that the court can only apply customary law in a dispute provided that it is not repugnant to justice. This gives the court the discretion to determine which customs are unjust and which are not. In doing so, the courts assess whether a certain practice is detrimental to the physical and emotional wellbeing of a person and also use laws from other states to determine what actions are repugnant to justice. In exercising this discretion, the courts may deem a custom as repugnant to justice and morality without fully evaluating the consequences of illegalising the custom. In Katet Nchoe and Nalangu Sekut $v$ R, ${ }^{39}$ the High Court held that the Maasai custom of circumcising females was repugnant to justice and morality. The courts disregarded the customs and practices of the Maasai and held that since female genital mutilation caused physical pain, it was repugnant to justice and morality based on the fact that this practice is harmful to the physical and social wellbeing of a citizen. The decision seems rational and well-informed but a further analysis makes it fall to pieces. The decision is unjust to uncircumcised Maasai women who are shunned by their male counterparts because of being uncircumcised. It does not answer the question whether the courts will compel Maasai men to marry their uncircumcised women. ${ }^{40}$

Kenyan courts are constitutionally empowered to use traditional dispute resolution mechanisms when resolving an issue. Article 159 (2) (c) of the constitution provides that courts are to be guided by the principles of traditional dispute resolution mechanisms. Article 159 (3) limits the application of traditional dispute resolution mechanisms by stating that they should not be used in a man-

39 Criminal Appeal No. 115 of 2010 consolidated with Criminal Appeal No. 117 of 2010.

40 Kariuki F, Customary law jurisprudence from Kenyan courts: implications for traditional justice systems', 7. 
ner that contravenes the Bill of Rights, is inconsistent with the constitution or other written laws or is repugnant to justice and morality or results in outcomes that are repugnant to justice and morality. Despite this limitation, it is still worth noting that the introduction of the use of traditional dispute resolution methods is a step up for customary law. From Article 159 (1) it is clear that judicial authority is derived from the people and is vested in and exercised by courts and tribunals established under the constitution. In exercise of that authority, the courts and tribunals are to ensure that justice is done to all, is not delayed and that it is administered without undue regard to procedural technicalities. ${ }^{41}$ Recognition of ADR and traditional dispute resolution mechanisms is thus predicated on these cardinal principles to ensure that everyone has access to justice (whether in courts or in other informal fora), and that disputes are to be resolved expeditiously and without undue regard to procedural hurdles that bedevil the court system as they are very informal. ${ }^{42}$ It also proceeds from the recognition of the diverse cultures of the various communities in Kenya as the foundation of the nation and cumulative civilization of the Kenyan people and nation. ${ }^{43}$ Most of these mechanisms are entwined within the cultures of most Kenyan communities which are also protected by the constitution under Article 11.

In the case of $\mathrm{R} v$ Mohamed Abdow Mohamed, ${ }^{44}$ Abdow Mohamed was charged for the murder of Osman Ali Abdi on October 19 2011 in Eastleigh. On the date of the trial, the prosecution made an application to court to mark the matter settled, based on Islamic laws and customs. The prosecution claimed that the accused's family had paid compensation to the deceased family in the form of camels, goats, and performed rituals. The rituals were a form of blood money given to the deceased's family. Further, the prosecution claimed that witnesses to the murder were not willing to testify and therefore they could not proceed with the case. The court upheld the application of the traditional dispute resolution system based on Article 159 and Article 157 of the Constitution of Kenya that allowed the Director of Public Prosecution to withdraw cases with the leave of the court. This is a reflection of the widening scope of traditional dispute resolution mechanisms into criminal law.

\footnotetext{
41 Muigua K, "Traditional dispute resolution mechanisms under Article 159 of the Constitution of Kenya (2010)http://www.kmco.co.ke/attachments/Article/107/A\%20PAPER\%20ON\%20 ADR\%20AND\%20ARTICLE\%20159\%20OF\%20CONSTITUTION.pdf on 7 December 2015.

42 Muigua K, 'Traditional dispute resolution mechanisms under Article 159 of the Constitution of Kenya', 6.

43 Article 11, Constitution of Kenya (2010).

44 [2013] eKLR.
} 
Apart from diverting cases from the criminal justice system by the use of traditional dispute resolution mechanisms, an emerging jurisprudence from the court entails awarding compensation for offences based on customary law. ${ }^{45}$ In $R$ $v$ Lenaas Lenchura ${ }^{46} \mathrm{~J}$ Emukule sentenced Lenaas Lenchura using customary laws on conviction of manslaughter. Lenchura, a World War II veteran, stabbed the deceased, after a dispute arose between the two on who would fetch water first. The deceased was 55 years while the accused was 89 years at the time of the fight and stabbing. After a plea bargain, the accused's charge of murder was reduced to manslaughter and he pleaded guilty. The prosecution argued that the court should take into account the fact that the accused was a first offender as well as the circumstances under which he killed the deceased. The accused's counsel submitted that water was a scarce resource in Samburu, a resource that carried the importance of life and death, and that the court should consider this. Due to the accused's advanced age and the inability of the government to provide water, a duty imposed on it by the constitution, J Emukule resorted to the customary laws of the accused. He sentenced the accused to five years suspended sentence and required him to pay compensation of one female camel to the family of the deceased according to their customs.

The application of traditional dispute resolution methods also enhances the citizens' access to justice. They entail the use of practices and customs of a community in resolving disputes. They form part of the cultural norms, values and traditions of a particular community. Thus, traditional disputes resolution mechanisms (TDRMs) are firmly embedded in the customary laws of a tribe or ethnic group. Consequently, the success of TDRMs in enhancing access to justice is pegged on the role and recognition of customary laws as a significant source of law. ${ }^{47}$

The 2010 Constitution championed the application of customary law by providing for the application of TDRMs, widening its scope to resolving disputes in criminal cases and the awarding of compensation. However, there are still numerous challenges that need to be addressed before the application of customary law can be ameliorated. For instance, the extent of the repugnancy clause is yet to be fully defined. Despite the fact that law is striving to right the

45 Kariuki F, Customary law jurisprudence from Kenyan courts: implications for traditional justice systems', 10.

46 Criminal Case No.19 of 2011.

47 Kariuki F, 'Applicability of traditional dispute resolution mechanisms in criminal cases in Kenya: case study of Republic v Mohamed Abdow Mohamed [2013] eKLR', Alternative Dispute Resolution Journal Vol.2 Issue 1 (2014). 
legislative wrongs that caused the deterioration of customary law, there are still difficulties that need to be tackled.

\section{Challenges Facing African Customary Law}

Today, the application of customary law by courts in pluralist jurisdictions presents at least two issues. It would be remiss to assume that the application of customary law in the courts both now and in the future is not fraught with difficulties. African societies have developed vastly since the pre-colonial period while customary law has not. Its unwritten nature, lack of precedence, inherent favouritism of the male gender, etc, are definite contributions to its lack of pliability in modern legal systems.

\section{i. Unwritten nature and lack of precedence}

In Kenya, courts apply the Constitution, Acts of Parliament, Common Law and the doctrines of Equity as per the Judicature Act. ${ }^{48}$ The 2010 Constitution includes customary law but limits it providing that it is not repugnant to justice and morality. ${ }^{49}$ This lack of formalisation can be attributed to the difficulty in establishing a particular customary law. This is mainly because (unlike state law, which tends to be uniform, and relatively stable, and is issued formally and publicized) customary law in African jurisdictions is diverse and 'remains largely unwritten, informal, and often difficult to ascertain. ${ }^{50}$ Furthermore, the lack of recorded precedence from recognised courts as opposed to informal traditional systems disqualifies the use of customary law as common law.

It is also the reason for the introduction of foreign legal systems since its unwritten character led to the belief that traditional African communities did not have any laws. These well-established legal systems overtook customary law and were applied by the colonialists, and as discussed above, degraded customary law. This slow abasement led to the lack of recognition of customary law as a formal law and thus, to the need to prove a customary law in evidence. In Ernest Kinyanjui Kimani v Muiru Gikanga and Another, ${ }^{51}$ the court held that where customary law was not notorious or written, the party relying on it must prove it in court.

\footnotetext{
48 Section 3, Judicature Act (Act no 14 of 1977).

49 Article 159(3), Constitution of Kenya (2010).

50 Juma L, 'Putting old wine in new wine skins, the customary code of Lerotholi and justice administration in Lesotho', in Fenrich J, The Future of African Customary Law (2011), 129-130.

51 [1965] EA 735.
} 
This rule further undermined the standing of customary law as the constitution, statutes, common law and equity are taken judicial notice of. ${ }^{52}$

While most legal professionals are conversant with the intricacies of the constitution, statutes and common law, judicial training for customary law is limited. The court needs to call in experts to verify customs and, with changing times, these experts may become fewer and far in between. This situation becomes direr in light of the fact that customary cases have no comprehensive precedent. When cases in native courts are concluded, the judge would deliver the judgment without explaining the rationale behind it. Thus there is little to learn from face-value reading if native cases. Rules, however, may be elicited from the entirety of a case but this still does not reveal the reasoning behind certain traditional practices.

As a result, customary laws must be pleaded as part of the facts. ${ }^{53}$ It should be noted that this rule can be explained by the fact that most customs and practices may be known by members of that community alone and cannot be easily verified if they are unwritten or unknown. It is unworthy of the court to blindly accept an uninformed position. A practice, just like any other material fact in a case, should be proved. Perhaps, in this assumption lies the challenge of its unwritten nature. Though the need to prove customary law as a fact is logical, it is moot for its formalisation as it severely undermines its status as a recognised law.

\section{ii. Repugnancy clause}

In the words of Ngugi wa Thiong'o: 'If we want to turn Africa into a new Europe. . . then let us leave the destiny of our countries to Europeans. They will know how to do it better than the most gifted among us. ${ }^{54}$ The colonial powers encountered problems in the attempt to create a unified legal system as manifested by the presence of different races in Kenya with conflicting ideas about a desirable legal system. ${ }^{55}$ As described above, the colonialists chose to implement the British legal system, African customary law and Islamic law in tandem with

\footnotetext{
52 Kariuki F, 'Customary law jurisprudence from Kenyan courts: implications for traditional justice systems', 8.

53 http://www.kenyalawresourcecenter.org/2011/07/ascertainment-and-prove-of-customary.html on 4 September 2015.

54 Thiong'o N 'In the name of the mother: reflections of a writer and his empire' James Currey Publishers, Suffolk, 2013, 25.

55 Ghai Y.P and McAuslan J 'Public law and political change in Kenya' Oxford University Press, London, 1970, 125.
} 
the British legal system having the more formal laws. The introduction of an extraneous law into Kenya is not sufficient to explain this conflict of law. However, the implementation of more than one legal system in the same jurisdiction is the likely cause. ${ }^{56}$

After Independence, there was need to settle this internal conflict of laws and the Judicature Act was passed along with its inclusion of the repugnancy clause. This Act, however, did not solve the conflict of law as the issue was not the morality of ${ }^{57}$ or the ability to achieve justice using customary law, but how to harmonise the different legal systems. Even now, with the promulgation of the 2010 Constitution of Kenya, customary law is provided for in the Judicature $\mathrm{Act}^{58}$ which stipulates that it is to guide all courts in civil matters provided that it is not repugnant to justice. ${ }^{59}$ The repugnancy clause has been in application since colonial times ${ }^{60}$ and its application has not been clearly defined since. To define the specific terms of the clause, that is, its justice and morality, ${ }^{61}$ would be inadequate as even the meanings of these two words themselves must be taken within the context of a specific circumstance surrounding a law.

There is a clear need to define the scope of the clause as the position now is that the court has the discretion to determine whether a certain custom or practice is repugnant to justice. This is an unsatisfying application as the court may view a practice in the abstract sense and consequently, may adjudicate without regard to the consequences of illegalising a certain practice. ${ }^{62}$ In Maria Gisege Angoi v Macella Nyomenda, ${ }^{63}$ the court was faced with the question whether a woman-towoman marriage custom among the Kisii was repugnant to justice and morality. A woman-to-woman marriage is a customary practice where a woman whose husband is dead "marries" another woman and chooses a male figure from her husband's clan to sire children for the dead husband. The High Court held that

56 McDowell M, 'Review of Antony Allot in 'New essays in African law' Cambridge University Press (1971), 102.

57 Opiyo A, 'Repugnancy clause s.3[2] judicature act, cap.8 of the laws of Kenya: a critical examination of the concepts of justice and morality' LLB Dissertation, University of Nairobi, October 1993, 7.

58 Cap. 8, Laws of Kenya

59 (This is reiterated in the Constitution), Article 159(3) Constitution of Kenya (2010).

60 Article 52, Order-In-Council (1891).

${ }^{61}$ Justice is defined as the quality of being just; righteousness, equitableness, or moral rightness at http://dictionary.reference.com/browse/justice on 8 December 2015, morality is defined as conformity to the rules of right conduct; moral or virtuous conductathttp://dictionary.reference. $\mathrm{com} /$ browse $/$ morality?s=t on 8 December 2015.

${ }^{62}$ Kariuki F, 'Customary law jurisprudence from Kenyan courts: implications for traditional justice systems', 10.

63. Civil Appeal No.1 of 1981. 
the practice was repugnant to justice and morality since it prevented the other woman from freely choosing whom to marry. Thus, there was no marriage. The decision did not take into account the circumstances of the local community and the intention underlying the practice. With changing times, the court is more likely to adapt its decision based on the societal norm of the time. This means that practices that fit under the terms of the repugnancy clause today may be deemed illegal and immoral in a few years' time. ${ }^{64}$ This clearly shows the need to define the specific or, at the very least, more specific purview of the application of the repugnancy clause.

\section{iii. Jurisdictional Issues}

Customary law, like any other law, has its equivalent of jurisdiction. It applies only to the members of its specific community. In the colonial period, African customary law was only applied when the parties were both Africans but that position changed with section 3 of the Judicature Act which states:

'The High Court and all subordinate courts shall be guided by African customary law in civil cases in which one or more of the parties is subject to it or affected by it, so far as it is applicable and is not repugnant to justice and morality or inconsistent with any written law, and shall decide all such cases according to substantial justice without undue regard to technicalities of procedure and without undue delay.'

This provision opened up the application of customary law in cases where one of the parties was a non-African but does not give guidance as to the circumstances when customary law can be applied to a non-African. Some scholars opine that the implication appears to be that where a non-African has dealt with an African in a transaction where it was clearly intended that customary law should apply the non-African should not escape the consequences of the application of customary law merely because he is not an African. ${ }^{65}$

In the case of a conflict in a transaction between two members of different Kenyan tribes clearly intending the application of customary law, it is unclear as to what specific tribal law will be used. In the circumstances of marriage or child custody, it is less complicated since in most traditional Kenyan communities the wife adopts the customs of the husband and thus his tribe's customary law will govern any conflict. Such a situation is more complicated in the case of criminal

\footnotetext{
64 Wambui Otieno v Joash Ocbieng Ougo and Omolo Siranga (1982-88)1 KAR (the court acknowledged that the day of reckoning for the burial practices of the Luo was fast approaching).

65 Harvey W, Introduction to legal system in East Africa, East Africa Literature Bureau, Kampala, 1975.
} 
law (which TDRMs are slowly penetrating). In the case of $\mathrm{R} v$ Mohamed Abdow Mohamed, ${ }^{66}$ Abdow Mohamed was charged for the murder of Osman Ali Abdi on October $19^{\text {th }}$ 2011in Eastleigh. On the date of the trial, the prosecution made an application to court to mark the matter settled based on Islamic laws and customs. The prosecution claimed that the accused's family had paid compensation to the deceased family in the form of camels, goats, and performed rituals. The rituals were a form of blood money to the deceased's family. If the victim and the murderer in the aforementioned case were not of the same tribe, then applying TDRMs would be more taxing because of the uncertainty of which tribe's customary law to apply.

It is arguable that the law of the victim and his or her family should be applied. In general statement, the customary law of the person affected by the transaction should be applied. Consider the case of Virginia Otieno v Ougo \& another: ${ }^{67}$ the court directed that the deceased be buried in accordance with the customs of his Luo clan and stated that there is no way in which an African citizen can divest himself of association with the tribe of his father. Mr Otieno, having been born and bred a Luo, remained a member of Luo tribe and subject to the customary law of the Luo people. In this circumstance, the person affected by the transaction was the deceased as it involved his burial place.

Traditionally, different tribes have different customs and laws thus it is difficult to pinpoint characteristics of law. Indigenous customary laws were not uniform: there were points of similarity which cut across ethnic groupings, but there were also enormous differences in structure of the laws and contents. These variations were brought about by different stages of economic and political development, different social and kinship systems or different religious beliefs and different cultural practices of the society. ${ }^{68}$ Although it is considerably easier to adjudicate according to the customary law of the region, the lack of area-based African courts brings the enormity and diversity of customary laws to the forefront.

[2013] eKLR.

\{1987\} KLR 371.

68 http://www.kenyalawresourcecenter.org/2011/07/african-customary-law-under-reception. html\#sthash.SGXv8N4w.dpuf on 24 August 2015. 


\section{iv. Legal Pluralism}

Legal pluralism is a key feature of African legal systems. ${ }^{69}$ The form of pluralism that permeates these systems derives from what is known as the principle of "legal centrism", which holds that all law emanates from the state and that rites developed and practiced by non-state actors, including religious and customary institutions, are law only to the extent that they are recognized by the state. $^{70}$ This feature is evident in the Kenyan legal context from the repugnancy clause which provides that customary law can only be applied in so far as it is consistent with written law and not repugnant to justice. ${ }^{71}$ Article 159 (2) (c) of the Constitution of Kenya provides that courts are to be guided by the principles of traditional dispute resolution mechanisms. Article 159 (3) limits the application of traditional dispute resolution mechanisms by stating that they should not be used in a manner that contravenes the Bill of Rights, is inconsistent with the constitution or other written laws or is repugnant to justice and morality or results in outcomes that are repugnant to justice and morality.

Recall the earlier discussion on how the colonialists applied customary law and formal law beside one another. This dual application of law can be credited as the beginning of pluralism in the Kenyan legal system. The amalgamation of foreign laws with indigenous laws often elicits opportunities for challenges and conflicts in interpretation and enforcement of the laws in many African societies. $^{72}$ Article 159(3) of the Constitution of Kenya states that TDRMs can only be applied if they are consistent with the Constitution, written law and the Bill of Rights. Article 50 (2) (p) states that an accused person in Kenya has the benefit of the least severe of the prescribed punishments for an offence. The use of the word 'prescribed punishment' again may be interpreted to mean that the same should be in written form and thus exclude the application of traditional criminal justice. These constitutional provisions lead to the inference that traditional justice systems are mostly intended for use in civil cases as mirrored by section 3(2) of the Judicature Act. ${ }^{73}$

69 Frémont J, 'Legal pluralism, customary law and human rights in francophone African countries' 40 Victoria University of Wellington Law Review (2009-2010), 149.

Griffiths J, 'What is legal pluralism' Journal of Legal Pluralism and Unofficial Law (1986), 1.

Section 3(2), the Judicature Act, Cap 8, Laws of Kenya.

72 Ige R A, 'Legal pluralism in Africa: challenges, conflicts and adaptation in a global village' Journal of Law, Policy and Globalisation Volume 34 (2015).

73 Tobiko K, The relationship between formal rule of law and local traditional justice mechanisms, the $18^{\text {th }}$ International Association of Prosecutors Annual Conference, Moscow, 8-12 September 2013 available online. 
On the ground, however, more Kenyans prefer to use traditional justice systems due to inadequate accessibility and the capacity gaps of the formal justice system. Thus, the former continues to be applied informally in criminal offences. In $\mathrm{R} v$ Mohamed Abdow Mohamed, ${ }^{74}$ the parties settled the dispute out of court and refused to attend court when the Director of Public Prosecutions refused to withdraw the prosecution. The prosecution was later withdrawn for lack of evidence. This situation presents a disparity between the formal law that only allows the application of traditional dispute resolution methods in minor criminal $\operatorname{cases}^{75}$ and the practice in communities. There is also a discrepancy between customary resolutions and international standards. In some communities, minors can be married off, ${ }^{76}$ which contravenes the international principle of the best interest of the child being paramount in all actions. ${ }^{77}$ The challenge most ignited by legal pluralism is the scope of the more informal laws. To what extent should customary law apply in civil and more so, criminal cases? The constitutional and written provisions need to be reflected in the practice on the ground.

\section{v. Difficulty of Application in Modern Situations}

Customary law or, more accurately, all the different customary laws of the tribes in Kenya, was formed on the basis of different societal norms and customs than today. Due to changing times, the legal system cannot reproduce the circumstances or context that these social norms operated in and by which they were enforced. Thus, the legal system has a creative function which is creates a new type of customary law that can be applied in today's context. ${ }^{78}$

Customary law is slow to establish and slow to adapt to modern situations. For example: it would be hard to adapt customary law to encompass or to govern cases on corporate law, intellectual property law or, especially, offshore drilling rights cases. ${ }^{79}$ This is a huge impediment as law is not limited to family, succession, property and criminal cases. It extends far beyond this, to apply to the increasingly capitalistic society that Kenya is today. It would hardly be reasonable to adapt customary law to govern legal or business ethics. In as much as the law

\footnotetext{
[2013] eKLR.

Section 176, Criminal Procedure Code (Rev. 2012).

Tobiko K, The relationship between formal rule of law and local traditional justice mechanisms, 14.

UNHCR Guidelines on Formal Determination of the Best Interests of the Child, 3 May 2008, 13.

Woodman G' How state courts create customary laws in Ghana and Nigeria' People's Law and State Law: the Bellagio Papers (1987), 182.

79 <http://www.quora.com/What-are-the-advantages-and-disadvantages-of-customary-law> on 3 September 2015.
} 
limits the application of customary law, customary law in itself applies to a limited number of modern scenarios.

\section{vi. Discrimination}

The Kenyan Constitution protects all minority classes in Kenya from discrimination and accords them equal benefit and equal protection of the law. ${ }^{80}$ This constitutional provision is paramount over all others as the constitution is the supreme law of the land. However, many women continue to suffer discrimination under customary systems that are favored by the rural population in Kenya. Instances of widows being dispossessed of their late spouses' property, wives being disadvantaged during divorce proceedings and women in cohabitation relationships not being recognised as legitimate spouses are not uncommon.

In Kenya, there is an intricate link between customary laws, customary practices and women's rights. Almost invariably, women occupy a disadvantaged position under customary law. This is because traditional African societies are governed on the basis of patriarchal structures where women's individual interests were subsumed under the interests of the group. Hence customary law contains aspects that often run counter to principles of gender equality and nondiscrimination espoused in both domestic and international human rights instruments. The continued application of customary law in areas such as succession and marriage engenders conflict with statutory provisions. ${ }^{81}$ Despite the equal inheritance provisions in the Law of Succession Act, it is unclear whether these provisions are actually being practised on the ground when using customary dispute resolution systems.

This raises conflicting issues about the extent of application of customary law in succession matters. While some courts have insisted on the exclusive applicability of the Law of Succession Act, other courts have maintained that customary law is generally applicable in succession matters, even where there is no express provision for it in the Act. ${ }^{82}$ Under this approach, customary law has been applied to deny women the right to inherit their father's or husband's estate, as happened in Mary Gichuru v Esther Gachubi. ${ }^{83}$ In contrast, in Mbinga v Mbinga, ${ }^{84}$

\footnotetext{
80 Article 27, Constitution of Kenya (2010).

81 Kamau W, 'Customary law and women's rights in Kenya' at http://theequalityeffect.org/wpcontent/uploads/2014/12/CustomaryLawAndWomensRightsInKenya.pdf on 8 December 2015.

82 Kamau W, 'Customary law and women's rights in Kenya', 17.

83 Civil Appeal No. 76 of 1998.

84 [2006] eKLR.
} 
Lady Justice Khaminwa appealed to the principles of non-discrimination enshrined in international treaties to which Kenya is a signatory, namely the Universal Declaration of Human Rights (UDHR) and Convention on the Elimination of All Forms of Discrimination Against Women (CEDAW), to override a customary law that allowed discrimination against married daughters in inheritance matters. In a bold articulation of gender equality, the judge noted that the custom of disinheriting daughters went against the current jurisprudence in international law which was making a concerted effort to ensure that there was no discrimination on the ground of gender. ${ }^{85}$

These conflicting court positions make it difficult for future applicators of customary law to decide what position should be taken. On top of the contrasting positions, most customary systems will opt to use their own customs and norms to adjudicate disputes and may be rightly backed by the former case. However, this position is contrary to a number of international treaties that Kenya has ratified and which now form part of the State's law. Suffice it to say, applying customary law can be challenging in some situations as it fosters discrimination against women and falls short of international standards.

\section{Possible Solutions}

The attitude of Kenya's legal system towards customary law is improving from its post-independence attitude. This is especially clear from the application of the aforementioned TDRMs applied by the court and the recognition of customary land rights and land-holding systems. Despite these improvements, there is still need to ensure that its usage is effective and promotes justice.

Firstly, greater respect should be accorded to customary law and traditional institutions. The preamble of the Swazi Constitution ${ }^{86}$ states that it is necessary to blend customary institutions with those of democratic society, and then the Constitution sets out the traditional pillars of the monarchy and states that traditional government is administered according to Swazi law and custom. ${ }^{87}$ Micronesian law requires all court decisions to be consistent with the customs and traditions of Micronesia. ${ }^{88}$ The stated positions may not work effectively in Kenya as there is a great diversity of customs due to the large number of tribes. However, sepa-

\footnotetext{
85 Kamau W, 'Customary law and women's rights in Kenya', 17.

86 Preamble, Constitution of the Kingdom of Swaziland (2005).

87 Section 227, Constitution of the Kingdom of Swaziland (2005).

88 Article XI section 11, Constitution of the Federated States of Micronesia (1975).
} 
rate traditional institutions may be established or tribes may be represented in established government institutions. At face value, the latter option may seem to exacerbate the already-rampant problem of tribalism in government institutions thus interfering with their integrity. The choice of electing parliamentarians and government officials is mostly based on tribe making the addition of more tribal elements to government redundant and even more, detrimental to the confidence of the people in the government. The former is a viable option as seen in Botswana where the law provides for a House of Chiefs, which submits resolutions to the National Assembly on Bills affecting customary issues. ${ }^{89}$ If even establishing separate traditional institutions seems taxing, then more respect and involvement should be accorded to the present traditional institutions like the Njuri Ncheke, the Nabongo and other traditional administration bodies in the making of laws, especially laws that affect customs and communal land.

Kenya can borrow a leaf from other African countries and establish courts with specific jurisdiction over customary law. ${ }^{90}$ The courts lack adequate knowledge and usually depend on the opinion of experts and the use of assessors. Most Kenyans are of indigenous Kenyan origin and thus subject to the customs of their tribe. No African can divorce himself from the tribe of his roots and thus he will always be under his tribe's law '...there is no way an African citizen of Kenya can divest himself of the association with the tribe of his father... ${ }^{91}$ This carries the implication that the majority of Kenyans filing claims in courts are party to a certain customary law and thus it is applicable in most cases. Therefore, establishment of customary courts, not unlike the native courts and tribunals of pre-independence Kenya or the African Courts of post 1951, may foster a more effective resolution of disputes using customary law. Customary courts may also prove to be faster, more easily accessible and cost-effective in promoting access to justice. ${ }^{92}$ However, if established, these courts should be given the same status and validity as other courts in Kenya. Establishment of these courts is advantageous as precedence can be built from the customary cases providing a way for the courts and the people to gain knowledge of customary law for posterity.

Customary elders can be educated on the national and international human rights' standards fostering non-discrimination in customary dispute resolu-

\footnotetext{
89 Sections 77 and 85, Constitution of Botswana (1966).

90 Article 78(5), Constitution of the Federal Democratic Republic of Ethiopia (1995); section 110(3), Constitution of the Republic of Malawi (1994); sections 265, 280, Constitution of the Federal Republic of Nigeria (1999).

91 Wambui Otieno v Joash Ochieng Ougo and Omolo Siranga (1982-88)1 KAR.

92 Article 48, the Constitution of Kenya (2010).
} 
tion. A Kenyan NGO, KELIN, developed an alternative approach for accessing justice for widows and their children who had been disinherited. Working with customary legal structures in Homa Bay and Kisumu, on the shores of Lake Victoria, KELIN helped rebuild community-based justice systems so that they respect Kenyan law and human rights. KELIN held community dialogues with widows, elders, and government officials to get their suggestions for the project. They then conducted trainings for elders and widows on the human rights provisions of Kenyan property and inheritance laws. Customary structures now are more equipped to address inheritance disputes. KELIN has taken on more than 100 cases involving disinheritance, the vast majority of which have been resolved with women and children back on their land. Cases adjudicated in this way take much less time than in the formal courts; an average of three months to resolve, compared to the average three years for court cases. ${ }^{93}$

Wider application of customary law can be applied if there was more comprehensive knowledge on customary law. As stated above, establishment of customary courts can lead to the building of precedence of customary cases. On top of this, judges, lawyers and future law students should be taught customary law formally much as they are taught common law principles and doctrines of equity. This task is quite daunting considering the fact that there are many diverse customs and an expert in every tribe for most tribes may be required for an accurate understanding of norms. The most reliable experts are traditionalists and they may not be adequately instucted to teach the legal aspect and implications of customary law. This perhaps is the most glaring challenge that can arise from the formal teaching of customary law.

Most of the suggestions above are riddled with challenges arising from the unwritten and diverse nature of customary law. Application of any one of the following suggestions may, however, help effect another, for example: establishing customary courts will help build a body of precedent that may then be used for the formal teaching of customary law. Effecting one of these or even other solutions is vital as it will expose customary law to public attention, anchoring it more firmly in Kenya's legal system.

93 http://www.endvawnow.org/en/Articles/762-addressing-customary-laws-and-practices-thatconflict-with-formal-laws.html on 10 December 2015. 


\section{Conclusion}

All great change in any state begins from the court. Just as a court ruled for the possession of human chattels legalising slavery ${ }^{94}$ and more recently, legalised gay marriage, ${ }^{95}$ the proper application of and emphasis accorded to customary law should continue to evolve from the court. It seems as if the answer to law in an African context lies somewhere other than in the application of a system premised on and designed for the western principles of individualism and capitalism. It cannot be repeated often enough that a legal system must reflect the people it serves if it is to gain their confidence. Clearly, the answer lies not in mimicking a western model of law but in accommodating different systems of law informed by the need to respect the right of communities to observe cultures and customs which they hold dear and to preserve customary law. This is the steel that will forge a better society true to its African identity.

94 Dred Scott v Sandford, 60 U.S. 393 (1857) (the plaintiff sued the defendant after she refused to let him purchase his and his family's freedom. The Supreme Court held that the state had no authority to interfere with how an owner uses his chattels).

95 Obergefell v Hodges (2015) (heard in the Supreme Court where the court stated that all states nationwide were required to legalise gay marriage). 